\title{
The Library of Congress and Its Service to Science and Technology
}

B $\mathrm{ACK}$ in the spring of $190 \mathrm{I}$ the $\mathrm{Li}$ brarian of Congress received an application from a student at the New York State Library School. He possessed admirable qualifications; he was, he said, personally known to Mr. Windsor, Mr. Flagg, and Mr. Ashley; he had met Mr. Martel; he was available at an annual compensation of one thousand dollars but agreed to settle for nine hundred and to report at the beginning of July. $\mathrm{He}$ remained until Feb. 4, 1903, and for all of that period served in the catalog division where for the most part he devoted his splendid energies and talents to that newfangled business called "card distribution." Charles Harris Hastings once commented on his abilities in a memorandum to Herbert Putnam in these terms:

$[\mathrm{He}]$ is now carrying the details connected with the current orders in a most satisfactory way. I hope he will be allowed to continue the work another year. Should like to feel that he was adequately paid for doing so well work which one who was not interested would consider drudgery and could not do successfully. ... I know that ... in filing the cards in our alphabet of printed cards, [he] finds dozens of mistakes (mostly misprints) in cards which have been through the hands of all the proof readers in the Printing Office and Catalogue Division.... I claim that the work... [he] is doing and will do (if he helps at card distribution) during the coming year, will be higher in character and greater in quantity than that done by the average cataloger in the $\$ 1200$ grade. I doubt if there are any in the Library, of the $\$ 900$ and $\$ 1000$ grades, who deserve promotion more than he.
Certainly that was praise from "Sir Hubert" and certainly it was well earned. The Library of Congress is proud of this alumnus and grateful for his distinguished contributions to the profession. His name, of course, is Charles Harvey Brown.

Now, it is an interesting fact that in the minds of many people the Library of Congress is regarded as a sort of department store of knowledge. If one examines, for example, a classified directory of stores in a given locality he will find listed therein shoe stores, grocery stores, music stores, etc. But curiously enough the department stores are seldom listed in such compilations of specialized emporia. Yet there are many persons who when they need the commodities offered by these stores go, not to the specialized shop, but to the department store.

In certain respects the Library of Congress resembles this parallel. For example, in 1943 the American Library Association published a Handbook of Medical Library Practice. It listed in an appendix a group of medical libraries which had one hundred thousand or more volumes in their collections. In this list the Library of Congress is conspicuous by its absence. Yet this library has within its walls a medical collection of over two hundred thousand volumes. Only the Army Medical Library and the library of the New York Academy of Medicine surpass it in size. It should be clearly understood however that the library does not now and has not for nearly a century attempted to secure an inclusive 
collection of the literature of the medical sciences nor has it pretended to the performance of specialized services in that field. On the contrary, the Library of Congress long ago conceded the national collection and the national service of materials on the ars curandi to the Army Medical Library.

Although the Library of Congress is not generally regarded as being a great scientific and technical library, yet it must respond to requests for every conceivable (and sometimes inconceivable) kind of scientific and technical information. The questions which the Library of Congress is called upon daily to answer range from Archimedean solids to zymology.

A random sampling of the day's grist to our mill includes such requests as the following: plans for the electric wiring system of a lake-going cargo vessel, how to build a baffle on a radio loud-speaker, a list of books on spiders and another on cannibalism, literature on the assembly of binoculars, the amount of blood pumped by the human heart in twenty-four hours, plans for a plant for the extraction of gonadotropic hormones, information on irregular polyhedra, where to buy an Army-type mine detector to be used in locating buried money, biographical information on foreign scientists, to say nothing of requests for information on the atom bomb, radar, biological warfare, socialized medicine, the sulfa-drugs and antibiotics, ultrasonics, isotopes, polarized light, the incidence of baldness in males, liquid sulfur dioxide, a list of books on aeronautics and also on a satisfactory sex life (one correspondent asked for lists on both topics but stated he was more interested in the first). With questions on the rickettsias, vivisection, and zeolites, we approach the end of the alphabet and this is only a very small sampling of the inquiries which hourly come in by the dozen, either through the mail, by telephone, or by personal presentation.

\section{Organization of Knowledge}

But the answering of questions is only one small aspect of our services to science and technology. Perhaps our greatest service and function is the collection and organization of knowledge and it is from this standpoint that I wish to discuss our con-. tributions to the advancement of science.

One of the features which distinguishes modern science from early craftsmanship and technology is the process of recording knowledge. Thus, the possibility of preserving and transmitting from one generation to the next, the observations of the motions of the stars and planets (observations which necessarily had to be collected over long periods of time), gave us the twin sciences of astronomy and mathematics.

If we regard the invention of writing as one of the great landmarks in the history of science, then we may look upon the invention of printing as another such event. For with the invention of printing mankind took a step forward toward the democratization of knowledge and this has had an enormously stimulating effect on the progress of science. One of the results of the democratization of knowledge is that it not only provokes thought and observation among large numbers of people but in so doing results in a cross-fertilization of ideas with a consequent increase in the sum of knowledge. Thus, the invention of printing provided one of the earliest examples of the now famous "chain reaction." And just as in an atomic chain reaction there must be a plentiful and freely available supply of neutrons to keep it going, so in the realm of ideas there must be a free and unrestricted interchange of information and ideas.

The printing of books began in the 
Western world in the latter half of the fifteenth century and it is possible to suggest that it may not have been mere accident that modern science as we know it today dates its birth from this achievement. Thus, for example, Copernicus in 1543 gave us his theory of the sun as the center of our planetary system and in that same year Vesalius produced the first modern anatomy. A year earlier Fuchs had printed his great classic on botany, and almost at the same time Agricola brought forth the first work on physical geology and the first work on mineralogy while in 1556 he introduced the first modern treatise on technology.

\section{Scientific Societies}

And it was also in the same century and a half that marked the beginnings of printing and the publication of some of the greatest works in modern science that we find the beginnings of the great scientific societies and academies.

At Naples in 1556 was formed the Accademia Secretorum Naturae and in Rome the Accademia dei Lincei. In 1662 Charles II granted the Royal Society its charter while in France an Académie des Sciences was founded by Louis XIV in 1666. Similar institutions were founded in other lands, and today the scientific and technical society is established as one of the foundation stones upon which the edifice of present-day science rests.

The scientific societies and academies were organized not merely to provide a meeting place for the exchange of ideas and to sponsor and encourage observation and experiment. From the first it was recognized that science was advanced only to the degree that its, results were disseminated. Thus it was that from the very beginning these societies and academies assumed as one of their .functions the publication of the results of researches by their members. From them came the first scientific journals which again, as agents in the democratization of knowledge, provided a great and continued impetus to the progress of civilization.

In 1846 occurred an event which was to have a special significance not only for the scientific life of this country but also for the Library of Congress. In that year there was established by Act of Congress an institution for the increase and diffusion of knowledge among men, to be known after its founder, James Smithson, as the Smithsonian Institution. Among the first acts of the organizers of the institution was the establishment of a library and the initiation of a series of scientific publications. The first secretary of the institution, Joseph Henry, one of the brightest luminaries in the American constellation, immediately began to correspond with societies and academies throughout the world for the purpose of entering into agreements for the exchange of publications. In a very short time there was accumulated in this way a remarkable collection of publications, theses, and other contributions to learning.

By 1865 the Smithsonian collection had grown to forty thousand volumes and it was becoming extremely difficult to find space for the library in the original building of the institution. Furthermore, a fire in that building (which could have been catastrophic) now made it imperative that new quarters be speedily found for the already invaluable repertory. Thus it was that when additional and commodious fireproof rooms were provided in the Capitol for the Library of Congress, the secretary of the Smithsonian Institution recommended that its books be deposited in the Library of Congress. In urging this action Joseph Henry wrote as follows:

The object of this transfer is not of course 
to separate this unique and highly prized collection of books from its relations to the Smithsonian Institution, for it must still bear its name and be subject to its control, but merely to deposit it where its preservation will be more certain and its usefulness more extended.

The act of transfer was approved by Congress on Apr. 5, I866. Of this transfer, Professor Henry later wrote:

The union of the library of the Institution with that of the Congress still continues to be productive of important results. The Smithson fund is relieved by this arrangement from maintenance of a separate library, while at the same time the Institution has not only the free use of its own books, but also those of the Library of Congress. On the other hand the collection of books owned by the Library of Congress would not be worthy of the name of the National Library were it not for the Smithsonian Deposit. The books which it receives from this source are eminently those which exhibit the progress of the world in civilization, and are emphatically those essential to the contemporaneous advance of our country in the higher science of the day.

True as these words of Joseph Henry were then, they are even more true today, for the forty thousand volumes of the original deposit have grown to almost a million. Indeed, this collection, continuously increasing in size, is probably the largest of its kind in the world. Because of the war-imposed destruction and dispersal of libraries in many parts of the world, the value of the Smithsonian deposit in the Library of Congress and its importance to scholarship, particularly to scientific research, has been markedly enhanced.

In addition to this collection there may be noted the library's vast accumulations of monographs, treatises, encyclopedias, and textbooks in the several disciplines which come to it either by the operation of the deposit requirements of the copyright act, by purchase, by transfer from government agencies, or by gift. These constitute a considerable portion of our total holdings in science and technology. Added to the materials which are issued through trade publishers are the large numbers of documents in which are recorded the results of investigations conducted by the scientific bureaus of our own and foreign governments.

Of special significance in this category are hitherto secret and confidential reports of civil and military offices of our own and allied governments, together with captured enemy documents which are now being declassified and made public. The Library of Congress is one of the depositories of these reports where they are available for consultation by all who need them. In addition, the library is cooperating with the Office of Technical Services of the Department of Commerce in making copies of these reports, in the form of photostats and microfilms, available to scientific laboratories, industrial organizations, libraries, and individuals.

To make known the contents of these reports the Office of Technical Services publishes each week an abstract journal which has the title Bibliography of Scientific and Industrial Reports. Accompanying each abstract is a report number and also the price of either a photostat or microfilm reproduction. Copies of these reports, which can be ordered only from the Office of Technical Services, U.S. Department of Commerce, are prepared by the Photoduplication Service of the Library of Congress and are usually delivered within ten days after the order is received. The library has already received more than 50,000 reports and has already sent out more than 65,000 microfilm and photostatic copies. The Army Medical Library and the library of the Department of Agriculture are also cooperating in this project to make research materials available to scholars everywhere. 
In addition to the reports which are being made available under the auspices of the Office of Technical Services is another series which the library is distributing for the Office of Scientific Research and Development. With the termination of hostilities it was felt that much of the research which had been performed by university and industrial laboratories under contract with the Office of Scientific Research and Development could safely be made public. Since many of these reports had been reproduced in multiple copies, it was decided that in order to make them available to as wide a public as possible they should be distributed to libraries rather than to individuals. Accordingly the Library of Congress in April 1946 undertook to arrange for the distribution of these reports to ninety selected libraries. Every effort was made so to distribute the reports that they could be readily accessible to those who needed them. A complete file of reports is deposited in the Library of Congress (except those in medicine which go to the Army Medical Library) so that they are available for the use of the Congress, the government, and the scientific public generally. It is estimated that more than two million copies of reports representing between thirty and thirty-five thousand titles will have been distributed when this project is completed.

Of smaller size but of no less significance are certain special collections in the Library of Congress. The most outstanding of these is our aeronautics collection. In 1930 through the munificence of Harry F. Guggenheim there was established the Daniel Guggenheim Fund for Aeronautics in the Library of Congress. This fund made possible the purchase of a number of famous collections of aeronautic literature, among them those of Gaston Tissandier ( 1800 items), Herman Hoernes
( 783 items), and Victor Silberer ( 895 items). Simultaneously, the National Aeronautics Association donated its collection to us and the Smithsonian Institution deposited the Langley Aeronautical Library. Thus in a very short time the collection attained a position of pre-eminence in its field. Now, as a result of the tremendous influx of documents and other materials released by war research agencies, such as the Office of Scientific Research and Development, the National Advisory Committee for Aeronautics, and the very important materials captured from the German Air Ministry, the resources of the division of aeronautics will indeed be second to none.

\section{History of Science}

For students of the history of science our general collections in science and technology provide, of course, the basic source materials. There are also several special collections which are distinguished and important; among these may be mentioned the Henry Carrington Bolton Collection of some 1600 items on the history and bibliography of chemistry. Our incunabula, according to a recent census, includes 536 items classified as "scientific." Then there is the Toner Collection, especially rich in early American works in science, medicine, and surgery. Finally, there is our collection of manuscripts wherein are found the personal papers of many scientific worthies, such as Franklin, Jefferson, Bigelow, Maury, the medical Bartletts, Einstein, and others. One of the most notable of our recent accessions is the Kastor Collection of two hundred pen and ink portraits of contemporary scientists, many of them Nobel prize winners, each bearing the sitter's autograph.

But despite the size of its scientific and technological collections the Library of Congress is not and cannot be complacent. Great as these holdings may appear to the 
cursory view they are in fact seriously and even appallingly deficient in many important respects. Probably the most obvious lacunae were discovered when, in attempting to meet the demands of the war agencies, we learned that many important foreign materials were lacking. Every effort is being made and will continue to be made to repair these critical shortcomings.

\section{Organization of Materials}

Parallel to the collection of materials is their organization for use. A collection of books placed upon a shelf is like water behind a dam. This quiescent body of water represents just so much potential energy. But let this water be channeled through conduits and brought in contact with turbines, and wheels begin to turn, power is generated, and productive work is the result. In a library, the instruments which convert the potential energy on its shelves into the kinetic energy of scientific advancement and productive scholarship are the catalogs, classification schedules, bibliographies, and other aids to access.

Let me carry the analogy a trifle farther. In a small water power installation, little elaborate machinery is required. In fact, a bladed wheel set in the path of the current is sufficient to produce power. So in a small library, little or no classification is required and it can even operate without a catalog. But in large installations, especially those which must distribute power over vast areas, the problems of channeling the water and converting the largest quantity of potential energy most efficiently make for a major engineering job.

The Library of Congress recognized quite early in its history that the classification of its materials would have to be performed on a vast scale, one commensurate not only with the size of its existing collections but also on a scale which would permit of expansion to keep pace with the advancement of knowledge. That the scheme of classification which was finally adopted has merit is attested by the fact that more than two hundred large American and foreign libraries use it.

The key to the library's informational resources which, in conjunction with the classification system, makes available the contents of our collections is the catalog. But no catalog organized on a universal principle, as ours is, can particularize and distinguish content to the extent of completely satisfactory mediation between the investigator and the book.

It seems evident, therefore, that the most manifest need of our collection is for interpreters, specialists who are not only versed in the subject matter of the several sciences but who have also the skill to use existing bibliographical tools and even to create new tools whenever necessary.

\section{Science and Technology}

For this reason the Congress has been asked to appropriate funds for the creation of a division of science and technology in the Library of Congress staffed by a corps of specialists competent to interpret the materials it now has and to recommend the acquisition of those it needs. Through the creation of such a division the library will be enabled to perform a reference service and develop a bibliographical program necessary to the fulfilment of its duty to the laboratory and the bench, to the classroom and the factory, the advancement of science, and the promotion of the public interest.

There is general agreement among both scientists and librarians that there should be some library in the country where the scientist should be able to find every possible piece of scientific information to supplement the working collections at his dispesal, a 
sort of federal reserve bank of scientific knowledge. And it seems further agreed that the Library of Congress is perhaps uniquely qualified to maintain and administer what may well be called the national science collection, because of the size and scope of its existing collections, because of the union catalog which enables the researcher to locate books which are not in his own library, and because of our photoduplication facilities which make it possible to provide any scientist or scholar the texts he requires no matter what his distance from the materials themselves.

Upon the basis of the informed opinion which we have consulted, an adequate science and technology division created to administer our collections in these fields should include a chief, fourteen subject specialists, twenty-one expert bibliographers together with secretarial and clerical assistants-altogether a total of forty-six persons. The fields covered by the subject specialists would comprehend geology; metallurgy; astronomy and mathematics, including statistics; nuclear physics; industrial physics, including optics, acoustics, and heat; organic chemistry and biochemistry; physical chemistry, including analytical, colloidal, and nuclear chemistry; chemical engineering; civil and structural engineering; mechanical engineering; electronics and electrical engineering; botany; morphological zoology, including comparative anatomy, cytology, histology, protozoology, and taxonomy; functional biology, including general and comparative physiology of plants and animals, physiological chemistry, biophysics, zymology, nutrition and perhaps viruses, bacteriophages, germicides, antibiotics, vitamins, and bio-assay techniques. The plan would recognize the Army Medical and Department of Agriculture Libraries as national special libraries in their respective fields.
In this connection it may be of interest to note that early in 1947 , at the request of the Office of Naval Research, the library established a science project which in a sense may be regarded as the pilot plant stage of the projected division of science and technology. The project will utilize the library's experience and talents in abstracting and indexing current scientific materials for the Navy bureaus. In addition, the project will provide temporarily a nucleus of specialists who will enable us to give as high a grade of reference and bibliographic service in several branches of science and technology as we now are able to give in certain other fields of knowledge.

\section{Program of Project}

The program of the project has three interrelated parts. First, it will abstract and publish for limited circulation, the technical reports of research in progress which O.N.R. receives from contractors working under Navy auspices. It will organize and index the file of such reports already received and provide a reference and loan service on the data which that file contains. Second, the staff of scientific specialists will be available to answer reference inquiries and prepare bibliographies needed not only by Navy bureaus and officials but by other users of the library as well, utilizing the collections of the library and those of other government libraries in Washington. Finally, the staff of the project will investigate the possibility of working out an indexing system for the records of current scientific research elastic enough to include an ever-increasing diversity of records and publications, which might form the basis for an eventual highspeed bibliographic service rendered by a central clearinghouse of information on current scientific research. 